\title{
Exostoses-anetodermia-brachydactyly type E syndrome
}

INSERM

\section{Source}

INSERM. (1999). Orphanet: an online rare disease and orphan drug data base. Exostosesanetodermia-brachydactyly type E syndrome. ORPHA:1962

Exostoses-anetodermia-brachydactyly type $\mathrm{E}$ syndrome is an association reported in a single kindred characterized by the variable presence of the following features:

anetodermia (macular atrophy of the skin), multiple exostoses, and brachydactyly type $\mathrm{E}$ (see this term). There have been no further descriptions in the literature since 1985. 